\title{
PENGARUH WAKTU PERENDAMAN STEK BATANG VANILI DALAM ZAT PENGATUR TUMBUH ROOTONE - F TERHADAP PERTUMBUHAN VANILI (VANILLA PLANIFOLIA ANDREWS)
}

\author{
Philipus.N.Supardi ${ }^{1}$, Silvester Seda ${ }^{1}$
}

Program Studi Agroekoteknologi Fakultas Pertanian Universitas Flores

\begin{abstract}
This study aims to determine the effect of immersion time with the vanilla stem cuttings of plan growth regulators Rotoone - F of credit for the growth of roots and shoots of vanilla cuttings.

The treatment used in this study is A0 (without immersion), A1 (immersion time $5 \mathrm{~min}$ ), A2 (soaking time $10 \mathrm{~min}$ ), and A3 (soaking time $15 \mathrm{~min}$ ) variable observation in this study is the number of shoots, root number, number of The first day of growing shoots, shoot length, root length, root diameter, wet weight and dry weight of cuttings of vanilla.

The results showed that root growth tebaik to treatment with the immersion time of $15 \mathrm{~min}$ (A3) is indicated by the highest number of roots, root length and diameter to treatment with the highest root of soaking time $15 \mathrm{~min}$ (A3) in 14 to 28 HST HST. The results showed that the growth of shoots best to treatment with the immersion time of 15 min (A3) is indicated by the number of days the first shoots to grow the fastest, most jumlahtunas, shoot length, wet weight and dry weight of the highest in treatments with soaking time 15 (A3) in 14 HST to 28 HST.
\end{abstract}

Kata Kunci : Waktu Perendaman, Rootone - F, Vanili

\section{PENDAHULUAN}

Vanili merupakan tanaman tropis bernilai ekonomi tinggi, karena merupakan rempah termahal kedua yang diperdagangkan di dunia internasional. Tahun 2002 harga vanili kering cukup tinggi berkisar Rp. 2.000.000,- hingga Rp.3.000.000/kg (Deptan, 2004). Harga vanili segar ratarata di pasar dalam negeri dari tahun 1999 sampai 2003 tidak stabil, dimana pada tahun 2003 harga vanili segar melonjak tajam mencapai Rp. $301.330 / \mathrm{kg}$. Tahun 2006 para petani di Kuningan dan Sumedang mengalami penurunan harga yakni Rp. 65.000/kg untuk vanili segar dan Rp.700.000/kg untuk vanili kering (Deptan, 2004).
Harga ekspor vanili yang tidak stabil dipasaran, dipengaruhi oleh ketersediaan barang, besarnya permintaan serta mutu barang.

Permasalahan ini menyebabkan produktivitas dan mutunya rendah. Produktivitas yang rendah dipengaruhi antara lain oleh tingkat kesesuaian lingkungan tumbuh, varietas, teknik budidaya dan serangan hama dan penyakit, sedangkan mutu vanili umumnya dipengaruhi oleh umur panen, panjang polong dan proses pengolahan setelah panen (kadar vanilin).

Stek batang sebagai bahan tanam (bibit), sebab batang mempunyai persediaan makanan yang cukup 
terhadap tunas-tunas batang dan akar, dan juga dapat dihasilkan dalam jumlah besar (Rochiman dan Hariadi, 1973). Upaya pembiakan secara vegetatif dengan tujuan untuk memperoleh persentase tumbuh tanaman yang tinggi, adanya peningkatan sistem pertumbuhan perakaran, serta bibit tanaman yang ditanam lebih mampu dan cepat beradaptasi dengan lingkungan yang baru perlu dilibatkan pula penggunaan hormon tumbuh akar melalui berbagi uji coba untuk mendapatkan konsentrasi dan lama perendaman yang tepat dalam penggunaannya sehingga diperoleh hasil yang lebih baik bagi pengaturan dan pertumbuhan tanaman (Anonimus, 1987).

Penanaman vanili dapat dilakukan dengan cara generatif dan vegetatif. Karena sulitnya penanaman secara generatif, para petani biasanya melakukan penanaman secara vegetatif melalui setek. Setek ini dapat langsung ditanam di kebun atau melalui pembibitan dahulu. Untuk setek yang langsung tanam di kebun dianjurkan paling sedikit mempunyai 5 buku. Makin panjang stek yang ditanam, makin cepat tanaman berbuah. Jika bahan tanaman terbatas, penggunaan stek pendek sepanjang 1 - 3 buku harus disemaikan dulu sampai 5-7 buku. Bahan tanaman yang digunakan sebagai bibit diambil dari batang induk yang mempunyai produksi tinggi dan bebas dari hama penyakit. Disamping itu, batang yang diambil sebaiknya belum pernah berbunga, mempunyai ruas yang pendek, dan diambil pada pertengahan musim penghujan pada saat pohon induk dalam keadaan aktif. Banyaknya stek yang diambil disesuaikan dengan jumlah pohon yang akan ditanam (sesuai dengan jarak tanamnya). Bibit vanili di Indonesia kebanyakan dalam jenis Vanilla planifolia Andrews. Bibit vanili yang sekarang banyak diintroduksikan ke petani adalah bibit vanili BIO-FOB dengan keunggulan pada ketahanan akan serangan penyakit busuk batang. (Latifah Irma 2006).

Salah satu hormon tumbuh akar yang banyak dipergunakan akhir-akhir ini adalah Rootone-F. Rootone-F berguna untuk mempercepat dan memperbanyak keluarnya akar-akar baru, karena mengandung bahan aktif dari hasil formulasi beberapa hormon tumbuh akar yaitu IBA (indolebutyric acid), IAA (indole-3-acetic acid), dan NAA (nepthaleneacetic acid). Penggunaan Rootone-F sebagai hasil kombinasi dari ketiga jenis hormon tumbuh di atas lebih efektif merangsang perakaran dari pada penggunaan hanya satu jenis hormon secara tunggal pada konsentrasi sama (Anonimus, 1987).

Zat pengatur tumbuh Rootone-F merupakan senyawa atau zat kimia yang dalam konsentrasi rendah dapat merangsang, menghambat atau sebaliknya menggubah proses fisiologis dalam pertumbuhan dan perkembangan tanaman, terutama pada bagian-bagian vegetatif dari tanaman, dimana hal ini tergantung dari tiap-tiap jenis tanaman atau sifat-sifat dari masing-masing jenis tersebut berasal (Wareing dan Philips, 1978 dalam Gadner, 1991). Rootone-F juga menyebabkan munculnya akar liar di daerah ruas batang bagian bawah (Salibury dan Ross, 1995). Rootone-F dengan konsentrasi 200 ppm diduga mengandung kosentrasi auksin yang optimal untuk memacu pertumbuhan dan perkembangan awal akar, sehingga jumlah akar yang terbentuk lebih banyak dibandingkan dengan stek yang diberikan konsentrasi 100 ppm Rootone-F yang dipandang kurang optimal untuk pertambahan jumlah akar. Hal ini didukung oleh pendapat Gadner dkk, (1991) yang mengemukakan bahwa kadar auksin 
yang optimal akan memacu pertumbuhan dan perkembangan awal akar.

Metode perendaman adalah metode praktis yang paling awal ditemukan dan sampai saat ini masih dipandang paling efektif. Stek yang berkayu lembut (sotwood, herbaceus) jumlah larutan yang diabsorbsi akan tergantung pada jumlah air yang diabsorbsi, karena itu metode perendaman sangat sesuai digunakan untuk tanaman herbaceus guna mencegah terjadinya keracunan pada tanaman (Audus, 1963). Berdasarkan prapenelitian yang dilakukan pada bulan Mei sampai Juni 2010, pengunaan Rootone-F dengan konsentrasi 200 ppm terhadap stek vanili dengan waktu perendaman kurang dari dari 5 menit dapat menghasilkan akar 2 minggu setelah penanaman. Pendapat ini juga didukung oleh Weaver (1972) menyatakan bahwa penggunaan metode celup dan waktu perendaman cepat memungkinkan aplikasi auksin dalam jumlah yang konstan, kurang dipengaruhi kondisi lingkungan dan larutan yang sama dapat digunakan berulang kali, namun karena metode celup cepat menggunakan konsentrasi tinggi, sehingga apabila konsentrasinya tidak tepat maka akan menimbulkan penghambatan tunas, daun menguning dan jatuh ataupun kematian stek.

Desa Puutuga, Kecamatan Ndona, Kabupaten Ende merupakan salah satu desa penghasil vanili terbesar di Kabupaten Ende. Produksi vanili di Desa Puutuga pada tahun 2005 sebesar $530 \mathrm{~kg} /$ tahun dan pada tahun 2009 mengalami penurunan sebesar 215 $\mathrm{kg} / \mathrm{thn}$. Salah satu upaya untuk mengatasi masalah tersebut yaitu dengan perbaikan teknik budidaya melalui proses pembiakan secara vegetasi dengan stek batang.
Penelitian ini dilakukan bertujuan untuk mempelajari pengaruh waktu perendaman stek batang vanili dengan zat pengatur tumbuh Rootone-F terhadap pertumbuhan vanili (Vanilla planifolia Andrews).

\section{METODELOGI PENELITIAN}

Penelitian dilaksanakan di Desa Manulondo Kecamatan Ndona Kabupaten Ende. Penelitian berlangsung selama 3 bulan yakni dari bulan September sampai November 2010.

Bahan yang digunakan dalam penelitian adalah stek vanili, Rootone-F dengan bahan aktif sebagai berikut (1 Naphthaleneacematide $(0,06 \%), 2$ Methyl - 1 - Naphthaleneacetic Acid $(0,033 \%), 3$ - Methyl - 1 Naphthaleneacematide $\quad(0,013 \%)$, Indole -3 - Butiryc Acid (0,057\%), Thiram (Tetramethyl thiuram disulfida) $(4,000 \%)$ (Anonim, 1987), sevin untuk mencegah pertumbuhan jamur, media semai stek ( tanah, pasir dan pupuk organik dengan perbandingan 1:1:1 ), air untuk melarutkan Rootone-F, daun kelapa sebagai naungan tempat pembibitan, dan bambu sebagai kerangka tempat pembibitan.

Alat-alat yang digunakan dalam penelitian ini adalah gunting pangkas untuk memotong bahan stek, ember plastik digunakan untuk merendam stek, polybag untuk tempat tumbuh, media tumbuh stek, sendok untuk mengambil hormon Rootone-F, gelas ukur untuk mengukur banyaknya air yang digunakan, hiter sebagai alat penyiram, mistar untuk mengukur panjang akar stek, alat tulis menulis, jangka sorong, oven, alat timbang Yamato untuk kitchen scale Rancangan penelitian yang digunakan 
rancangan acak kelompok (RAK) dengan 4 perlakuan yaitu, A0 : Konsentrasi 0 ppm, tanpa menggunakan waktu perendaman (kontrol), A1 : Konsentrasi 200 ppm, direndam selama 5 menit, A2 : Konsentrasi 200 ppm, direndam selama 10 menit, A3 : Konsentrasi 200 ppm, direndam selama 15 menit, Perlakuan ini diulang sebanyak 6 kali dimana tiap-tiap perlakuan terdiri atas 3 stek, sehingga terdapat 72 satuan percobaan.

Variabel yang diamati adalah, Jumlah Akar Stek Jumlah akar stek yaitu dengan cara menghitung jumlah akar terbentuk dari setiap stek, Panjang Akar Panjang akar dihitung pada saat tanaman vanili didestruktif dengan menghitung panjang akar yang terbentuk dari setiap stek, 3. Diameter Akar, Diameter akar dihitung dengan mengukur diameter akar yang terbentuk dari stek vanili, Jumlah Hari Tumbuh Tunas Pertama Hari tumbuh tunas pertama di lihat dari hari awal penanaman sampai hari tumbuh tunas, Jumlah Tunas, Jumlah tunas yang muncul dari setiap stek dihitung dari jumlah tunas yang muncul pertama setelah penanaman stek vanili, Panjang Tunas, Panjang tunas dihitung dengan mengukur panjang tunas yang terbentuk, Berat Basah Stek Vanili, Berat basah stek diukur dengan cara menimbang stek vanili, Berat Kering Stek Vanili, Dihitung dari berat setelah dioven pada suhu $80^{\circ} \mathrm{C}$ sampai diperoleh berat konstan

Data dianalisis menggunakan analisis sidik ragam. Apabila perlakuan menunjukkan pengaruh yang nyata terhadap variabel yang diamati, maka dilanjutkan dengan Uji BNT 5\% (Gomez dan Gomez, 1995 ).

\section{HASIL DAN PEMBAHASAN}

\section{Jumlah Akar}

Hasil analisis sidik ragam menunjukkan bahwa waktu perendaman zat pengatur tumbuh Rootone-F memberikan pengaruh yang sangat nyata terhadap jumlah akar dari stek vanili. Jumlah akar stek vanili tertinggi pada perlakuan A3 dan terendah pada perlakuan A0. (Tabel 1).

Tabel 1. Pengaruh waktu perendaman stek vanili dengan menggunakan Rootone-F terhadap jumlah akar stek vanili (Vanilla planifolia Andrew).

\begin{tabular}{cccc}
\hline \multirow{2}{*}{ PERLAKUAN } & \multicolumn{3}{c}{ Jumlah Akar Pada Berbgai Umur Pengamatan } \\
\cline { 2 - 4 } & $\mathbf{1 4}$ & $\mathbf{2 1}$ & $\mathbf{2 8}$ \\
\hline A0 & $1,15 \mathrm{a}$ & $1,25 \mathrm{a}$ & $1,51 \mathrm{a}$ \\
A1 & $1,25 \mathrm{a}$ & $1,35 \mathrm{a}$ & $1,75 \mathrm{~b}$ \\
A2 & $1,51 \mathrm{a}$ & $1,63 \mathrm{a}$ & $1,98 \mathrm{c}$ \\
A3 & $1,83 \mathrm{~b}$ & $2,10 \mathrm{~b}$ & $3,08 \mathrm{~d}$ \\
\hline BNT 5\% & $\mathbf{0 , 3 7}$ & $\mathbf{0 , 3 7}$ & $\mathbf{0 , 2 2}$
\end{tabular}

Keterangan: Angka-angka yang diikuti oleh huruf yang sama pada kolom yang sama berarti tidak berbeda nyata pada taraf uji BNT $5 \%$.

Jumlah akar stek vanili tertinggi pada perlakuan Rootone-F dengan waktu perendaman 15 menit. Hal ini disebabkan unsur-unsur yang ada dalam
Rootone-F akan menggantikan peran daun dan kuncup dari stek vanili yang telah hilang akibat pemotongan. Semakin lama waktu perendaman 
dengan menggunakan Rootone-f, maka semakin banyak unsur yang diserap oleh stek vanili sehingga dapat meningkatkan jumlah akar.

Hasil penelitian ini senada dengan penelitian yang dilakukan oleh Dwijoseputro (1980) yang mengatakan bahwa kehadiran tunas pada stek akan membantu proses pembentukan zat pengatur tumbuh yang kemudian diedarkan ke bagian bawah atau basal untuk membentuk akar. Untuk pembentukan akar pada stek vanili (Vanilla planifolia Andrew) digunakan zat pengatur tumbuh Rooone-F karena daun muda dan kuncup yang kaya akan auksin telah dihilangkan, dengan hilangnya organ tersebut pembentukan akar untuk stek vanili (Vanilla planifolia Andrew) akan lama terbentuk jika tanpa melibatkan penggunaan zat pengatur tumbun Rootone-F. Dengan pemberian Rootone-F organ tanaman (tunas muda dan kuncup) yang tadinya dihilangkan dan berfungsi untuk mensintesis auksin telah dipulihkan kemampuannya untuk membentuk akar dengan baik dan cepat.

\section{Panjang Akar.}

Hasil analisis sidik ragam menunjukkan bahwa waktu perendaman zat pengatur tumbuh Rootone-F memberikan pengaruh yang nyata terhadap panjang akar stek vanili. Panjang akar stek vanili tertinggi pada perlakuan A3 dan terendah pada perlakuan A0. (Tabel 2).

Tabel 2. Pengaruh waktu perendaman stek vanili dengan menggunakan Rootone-F terhadap panjang akar stek vanili (Vanilla planifolia Andrew).

\begin{tabular}{cccc}
\hline \multirow{2}{*}{ PERLAKUAN } & \multicolumn{3}{c}{ Panjang Akar Pada Berbgai Umur Pengamatan } \\
\cline { 2 - 4 } & $\mathbf{1 4}$ & $\mathbf{2 1}$ & $\mathbf{2 8}$ \\
\hline A0 & $2,01 \mathrm{a}$ & $2,29 \mathrm{a}$ & $5,37 \mathrm{a}$ \\
A1 & $2,34 \mathrm{a}$ & $2,63 \mathrm{a}$ & $6,23 \mathrm{a}$ \\
A2 & $3,16 \mathrm{~b}$ & $3,51 \mathrm{~b}$ & $7,68 \mathrm{~b}$ \\
A3 & $3,71 \mathrm{~b}$ & $4,05 \mathrm{~b}$ & $10,98 \mathrm{c}$ \\
\hline BNT 5\% & $\mathbf{0 , 7 2}$ & $\mathbf{0 , 5 5}$ & $\mathbf{1 , 1 7}$ \\
\hline
\end{tabular}

Keterangan: Angka-angka yang diikuti oleh huruf yang sama pada kolom yang sama berarti tidak berbeda nyata pada taraf uji BNT $5 \%$.

Panjang akar stek vanili tertinggi pada perlakuan Rootone-F dengan waktu perendaman 15 menit. Tanaman pada umumnya dapat mensintesis hormonnya sendiri yakni auksin endogen (Fithohormon) pada organ tertentu yang pada gilirannya berfungsi untuk merangsang terjadinya respon pada organ lain. Namun seringkali pasokan hormon yang secara alami ini dibawah optimal, terlebih pula untuk stek vanili (Vanilla planifolia Andrew) sangat membutuhkan tambahan hormon pengatur tumbuh yang berasal dari luar atau hormon sintetik yakni Rootone-F untuk menghasilkan respons yang dikehendaki. Rootone-F dan auksin endogen (yang dihasilkan oleh organ tanaman), bertindak secara bersamasama untuk menggalakkan suatu respon, yaitu pembentukan dan pemanjangan sel-sel akar.

Menurut Manurung (1987) menyatakan bahwa Rootone-F merupakan hormon pemacu pertumbuhan akar yang sudah umum digunakan. Rootone-F terdiri atas senyawa-senyawa yang menjadi bahan aktifnya yaitu 1-naphtalene-acetamide (NAD) $\quad 0,067 \%, \quad 2$-methyl-1- 
naphtaleneacetic acid (MNAA) 0,333\%, 3-methyl-1-naphtalene-acetamide

(MNAD) 0,013\%, indole-3-butiric acid (IBA) $0,051 \%$ serta tetramethyl-thiuram disulfide (Thiram) 4\%. Komposisi bahan aktif yang ada dalam Rootone-F maka Rootone-F tidak digolongkan dalam hormon tetapi lebih tepat sebagai zat pengatur tumbuh karena kandungan Thiram yang relatif tinggi dibandingkan bahan aktif lainnya.

\section{Diameter Akar.}

Hasil analisis sidik ragam menunjukan bahwa, waktu perendaman zat pengatur tumbuh Rootone-F memberikan pengaruh yang sangat nyata terhadap diameter akar yang dihasilkan dari stek vanili (Vanilla planifolia Andrew). Diameter akar stek vanili tertinggi pada perlakuan A3 dan terendah pada perlakuan A0. (Tabel 3).

Tabel 3. Pengaruh waktu perendaman stek vanili dengan menggunakan Rootone-F terhadap diameter akar stek vanili (Vanilla planifolia Andrew).

\begin{tabular}{cccc}
\hline \multirow{2}{*}{ PERLAKUAN } & \multicolumn{3}{c}{ Diameter Akar Pada Berbgai Umur Pengamatan } \\
\cline { 2 - 4 } & $\mathbf{1 4}$ & $\mathbf{2 1}$ & $\mathbf{2 8}$ \\
\hline A0 & $0,10 \mathrm{a}$ & $0,19 \mathrm{a}$ & $0,29 \mathrm{a}$ \\
A1 & $0,19 \mathrm{~b}$ & $0,25 \mathrm{~b}$ & $0,35 \mathrm{a}$ \\
A2 & $0,21 \mathrm{~b}$ & $0,27 \mathrm{~b}$ & $0,40 \mathrm{a}$ \\
A3 & $0,23 \mathrm{~b}$ & $0,32 \mathrm{c}$ & $0,53 \mathrm{~b}$ \\
\hline BNT 5\% & $\mathbf{0 , 0 2}$ & $\mathbf{0 , 0 5}$ & $\mathbf{0 , 0 7}$
\end{tabular}

Keterangan: Angka-angka yang diikuti oleh huruf yang sama pada kolom yang sama berarti tidak berbeda nyata pada taraf uji BNT $5 \%$.

Tabel 3 menunjukkan bahwa diameter akar stek vanili terting terdapat pada pada perlakuan Rootone-F dengan waktu perendaman 15 menit. Hal ini disebabkan oleh adanya senyawa 1naphtalene-acetamide (NAD) $0,067 \%$, 2-methyl-1-naphtaleneacetic acid (MNAA) 0,333\%, 3-methyl-1naphtalene-acetamide (MNAD) 0,013\%, indole-3-butiric acid (IBA) $0,051 \%$ serta tetramethyl-thiuram disulfide (Thiram) 4\% yang membantu hormon auksin yang terdapat dalam stek vanili untuk membantu pertumbuhan akar sehingga diameter akar pada perlakuan Rootone-F dengan waktu perendaman 15 menit lebih tinggi karena tingkat penyerapan Rootone-F lebih lama karena menurut Salisbury dan Ross (1995) mengatakan bahwa pemberian Rootone-F merangsang proses morfologis. Jaringan khalus yang terbentuk pada stek sebagai akibat respons tumbuhan terhadap pemberian Rootone-F berfungsi untuk memacu proses diferensiasi sel pada jaringan merismatik, dimana jaringan merismatik pada batang mengandung meristem difus yang memiliki jumlah sel sedikit dan aktivitas selnya rendah sehingga dibutuhkan hormon eksternal (RootoneF) untuk pertumbuhannya. Rootone-F yang diberikan pada stek akan bekerja secara bersama-sama dengan hormon alami yang akan diproduksi pada tanaman untuk mempercepat pembentukan khalus. Semakin cepatnya khalus terbentuk pada bagian potongan dasar stek tanaman, akan lebih cepatnya terbentuk akar kerena akar akan berdiferensiasi dari khalus. Pemberian Rootone-F juga menyebabkan munculnya akar liar di daerah ruas batang bagian bawah. 
Jumlah Hari Tumbuh Tunas Pertama.

Hasil analisis sidik ragam menunjukan bahwa, waktu perendaman stek vanili dengan zat pengatur tumbuh Rootone-F memberikan pengaruh yang sangat nyata terhadap jumlah hari tumbuh tunas pertama dari stek vanili (Vanilla planifolia Andrew). Jumlah hari tumbuh tunas tercepat pada perlakuan A3 dan terlama pada perlakuan A0. (Tabel 4).

Tabel 4. Pengaruh waktu perendaman stek vanili dengan menggunakan Rootone-F terhadap jumlah hari muncul tunas pertama stek vanili (Vanilla planifolia Andrew).

\begin{tabular}{cc}
\hline PERLAKUAN & RATAAN \\
\hline A0 & $21,33 \mathrm{a}$ \\
A1 & $20,66 \mathrm{~b}$ \\
A2 & $19,66 \mathrm{~b}$ \\
A3 & $15,66 \mathrm{~b}$ \\
\hline BNT 5\% & 1,27 \\
\hline
\end{tabular}

Keterangan: Angka-angka yang diikuti oleh huruf yang sama pada kolom yang sama berarti tidak berbeda nyata pada taraf uji BNT $5 \%$.

Jumlah hari tumbuh tunas pertama pada stek vanili tercepat pada perlakuan Rootone-F dengan waktu perendaman 15 menit. Hal ini disebabkan adanya unsur-unsur yang mengadung senyawa 1-naphtaleneacetamide (NAD) 0,067\%, 2-methyl-1naphtaleneacetic acid (MNAA) 0,333\%, 3-methyl-1-naphtalene-acetamide (MNAD) 0,013\%, indole-3-butiric acid (IBA) $0,051 \%$ serta tetramethyl-thiuram disulfide (Thiram) 4\% yang merangsang pertumbuhan tunas menjadi lebih cepat dari perlakuan yang lain. Sehingga dengan waktu perendaman selama 15 menit menggunakan Rootone-f membantu pertumbuhan tunas dalam hal membuat tunas yang muncul pada stek vanili semakin cepat karena banyaknya zat pengatur tumbuh Rootone-f yang diserap oleh stek vanili, karena menurut Wudianto (1999) menyatakan bahwa stek sebaiknya diambil dari cabang yang tidak terlalu muda ataupun tidak terlalu tua.

\section{Jumlah Tunas.}

Hasil analisis sidik ragam menunjukan bahwa, waktu perendaman stek vanili dengan zat pengatur tumbuh Rootone-F memberikan pengaruh yang sangat nyata pada jumlah tunas yang dihasilkan dari stek vanili (Vanilla planifolia Andrew). Jumlah tunas tertinggi pada perlakuan A3 dan terendah pada perlakuan A0. (Tabel 5). 
Tabel 5. Pengaruh waktu perendaman stek vanili dengan menggunakan Rootone-F terhadap jumlah tunas stek vanili (Vanilla planifolia Andrew).

\begin{tabular}{cccc}
\hline \multirow{2}{*}{ PERLAKUAN } & \multicolumn{3}{c}{ Jumlah Tunas (cm) Pada Berbgai Umur Pengamatan } \\
\cline { 2 - 4 } & $\mathbf{1 4}$ & $\mathbf{2 1}$ & $\mathbf{2 8}$ \\
\hline A0 & $0,16 \mathrm{a}$ & $0,83 \mathrm{a}$ & $1,00 \mathrm{a}$ \\
A1 & $0,50 \mathrm{a}$ & $1,00 \mathrm{~b}$ & $1,33 \mathrm{a}$ \\
A2 & $0,83 \mathrm{a}$ & $1,16 \mathrm{~b}$ & $1,50 \mathrm{a}$ \\
A3 & $1,00 \mathrm{~b}$ & $1,66 \mathrm{c}$ & $2,33 \mathrm{~b}$ \\
\hline BNT 5\% & $\mathbf{0 , 5 5}$ & $\mathbf{0 , 5 1}$ & $\mathbf{0 , 5 9}$ \\
\hline
\end{tabular}

Keterangan: Angka-angka yang diikuti oleh huruf yang sama pada kolom yang sama berarti tidak berbeda nyata pada taraf uji BNT $5 \%$.

Jumlah tunas stek vanili paling tinggi terdapat pada perlakuan Rootone dengan waktu perendaman 15 menit. Hal ini disebabkan oleh pemberian zat pengatur tumbuh Rootone-Fyang mengandung unsur-unsur yang memacu pertumbuhan akar yang panjang dan banyak sehingga tunas yang muncul menjadi lebih banyak. Stek vanili yang muda juga sangat membantu dalam proses pembentukan tunas, karena dalam stek vanili yang muda terdapat pembuluh xylem dan floem yang masih aktif menyerap unsur yang diberikan termasuk zat pengatur tumbuh RootoneF Wudianto (1999), Sehingga jika dipacu dengan zat pengatur tumbuh Rootone-f maka pertumbuhan stek vanili khususnya jumlah tunas akan lebih banyak. Dari segi ukuran pun setek yang berasal dari jaringan yang sedikit berkayu dan berkayu cenderung mempunyai umuran yang lebih besar dibanding setek yang berasal dari jaringan lunak yang diambil dari bagian arah ke pucuk tanaman. Kandungan cadangan makanan terutama karbohidrat nitrogen dan auksin pada stek dapat

menghasilkan pertumbuhan tunas dan akar yang baik atau seimbang pertumbuhannya, sehingga persentase hidupnyapun menjadi tinggi. Pertumbuhan tunas pada stek adalah sangat penting untuk menstimulir terbentuknya akar pada stek dan akar yang terbentuk ini akan menyerap unsur hara dari tanah yang selanjutnya akan ditranslokasikan ke atas melalui jaringan xylem untuk pertumbuhan tunas dan daun sehingga tunas dan akar yang tumbuh dapat seimbang dalam pertumbuhannya.

\section{Panjang Tunas.}

Hasil analisis sidik ragam menunjukan bahwa, waktu perendaman stek vanili dengan zat pengatur tumbuh Rootone-F memberikan pengaruh yang sangat nyata pada panjang tunas yang dihasilkan dari stek vanili (Vanilla planifolia Andrew). Panjang tunas tertinggi pada perlakuan A3 dan terendah pada perlakuan A0. (Tabel 6). 
Tabel 6. Pengaruh waktu perendaman stek vanili dengan menggunakan Rootone-F terhadap panjang tunas stek vanili (Vanilla planifolia Andrew).

\begin{tabular}{cccc}
\hline \multirow{2}{*}{ PERLAKUAN } & \multicolumn{3}{c}{ Panjang Tunas (cm) Pada Berbgai Umur Pengamatan } \\
\cline { 2 - 4 } & $\mathbf{1 4}$ & $\mathbf{2 1}$ & $\mathbf{2 8}$ \\
\hline A0 & $1,09 \mathrm{a}$ & $1,73 \mathrm{a}$ & $1,98 \mathrm{a}$ \\
A1 & $1,24 \mathrm{a}$ & $1,83 \mathrm{a}$ & $2,26 \mathrm{a}$ \\
A2 & $1,25 \mathrm{a}$ & $2,15 \mathrm{a}$ & $3,16 \mathrm{a}$ \\
A3 & $1,82 \mathrm{~b}$ & $3,43 \mathrm{~b}$ & $5,23 \mathrm{~b}$ \\
\hline BNT 5\% & $\mathbf{0 , 2 8}$ & $\mathbf{0 , 4 8}$ & $\mathbf{1 , 0 5}$ \\
\hline
\end{tabular}

Keterangan: Angka-angka yang diikuti oleh huruf yang sama pada kolom yang sama berarti tidak berbeda nyata pada taraf uji BNT $5 \%$.

Tabel 6 menunjukkan bahwa panjang tunas paling tinggi pada perlakuan Rootone-F dengan waktu perendaman 15 menit. Hal ini disebabkan oleh pemberian zat pengatur tumbuh Rootone-F dengan waktu perendaman 15 menit diangkut melalui jaringan floem ke dasar potongan stek vanili akan merangsang pembentukan akar dan tunas yang kuat dan juga mengakibatkan pertumbuhan yang kuat pula, sehingga proses perpanjang tunas dapat terjadi baik, Hartman dan Kester (1975). Pertumbuhan tunas yang baik menyebabkan pembentukan akar akan baik dan pembentukan akar yang baik maka pembentukan daun akan baik, sehingga proses fotosintesis dan pembuatan auxin dari tunas juga baik. Pertumbuhan akar yang baik menyebabkan unsur hara dan air yang diserap lebih banyak, sehingga pertumbuhan tunas menjadi lebih baik pula. Hal ini terkait dengan kerja enzim dan hormon terutama auksin dalam pembentukan tunas dan akar. Menurut Goldsworthy dan Fisher (1992), tersedianya kandungan karbohidrat yang banyak cenderung meningkatkan proses fisiologis pada tanaman dalam hal pembelahan, pembesaran dan pembentukan jaringan. Pemberian Rooton-F dalam penelitian ini membantu optimalisasi dari kerja enzim dan hormon yang terdapat dalam stek. Kusumo (1984) mengemukakan, Rootone $\mathrm{F}$ adalah formulasi dari beberpa zat yaitu NAD 0,067\%, MNAD 0,013\% MNAA 0,033\%, IBA 0,057\%, Thyram $4.00 \%$ yang merupakan senyawa organik yang dapat mempercepat dan memperbanyak perakaran stek sehingga yang tunas yang dihasilkan semakin panjang dan banyak.

\section{Berat Basah.}

Hasil analisis sidik ragam menunjukan bahwa, waktu perendaman stek vanili dengan zat pengatur tumbuh Rootone-F memberikan pengaruh yang sangat nyata pada berat basah yang dari stek vanili (Vanilla planifolia Andrew). Berat basah tertingi pada perlakuan A3 dan terendah pada perlakuan A0. (Tabel 7). 
Tabel 7. Pengaruh waktu perendaman stek vanili dengan menggunakan Rootone-F terhadap berat basah stek vanili (Vanilla planifolia Andrew).

\begin{tabular}{cccc}
\hline \multirow{2}{*}{ PERLAKUAN } & \multicolumn{3}{c}{ Berat Basah Pada Berbgai Umur Pengamatan } \\
\cline { 2 - 4 } & $\mathbf{1 4}$ & $\mathbf{2 1}$ & $\mathbf{2 8}$ \\
\hline A0 & $99,03 \mathrm{a}$ & $124,37 \mathrm{a}$ & $143,22 \mathrm{a}$ \\
A1 & $107,94 \mathrm{a}$ & $127,11 \mathrm{a}$ & $162,66 \mathrm{~b}$ \\
A2 & $115,34 \mathrm{a}$ & $134,23 \mathrm{~b}$ & $176,05 \mathrm{c}$ \\
A3 & $121,69 \mathrm{~b}$ & $144,27 \mathrm{c}$ & $217,44 \mathrm{~d}$ \\
\hline BNT 5\% & $\mathbf{9 , 0 5}$ & $\mathbf{1 2 , 7 2}$ & $\mathbf{1 2 , 5 3}$
\end{tabular}

Keterangan: Angka-angka yang diikuti oleh huruf yang sama pada kolom yang sama berarti tidak berbeda nyata pada taraf uji BNT $5 \%$.

Berat basah merupakan aspek pertumbuhan yang menggambarkan hasil kombinasi faktor-faktor pertumbuhan jumlah akar, diameter akar, panjang akar, jumlah tunas, panjaang tunas dan jumlah daun. Berat basah tertinggi dihasilkan oleh perlakuan dengan waktu perendaman stek vanili selam 15 menit. Dari hasil analisis, waktu perendaman 15 menit berbeda nyata terhadap berat basah stek vanili, karena banyaknya unsur hara dan air yang diserap oleh stek vanili yang direndam selama 15 menit akan mempercepat aspek-aspek pertumbuhan sehingga secara langsung menambah berat basah stek vanili, Kusumo (1984). Kadar optimum hormon untuk pertumbuhan akar jauh lebih rendah kira-kira 1.100.000 dari kadar optimum untuk pertumbuhan batang . Zat

Tabel 8. Pengaruh waktu perendaman stek vanili dengan menggunakan Rootone-F terhadap berat kering stek vanili (Vanilla planifolia Andrew).

\begin{tabular}{cccc}
\hline \multirow{2}{*}{ PERLAKUAN } & \multicolumn{3}{c}{ Berat Kering $(\mathbf{c m})$ Pada Berbgai Umur Pengamatan } \\
\cline { 2 - 4 } & $\mathbf{1 4}$ & $\mathbf{2 1}$ & $\mathbf{2 8}$ \\
\hline A0 & $12,58 \mathrm{a}$ & $14,80 \mathrm{a}$ & $14,78 \mathrm{a}$ \\
A1 & $14,01 \mathrm{~b}$ & $17,68 \mathrm{~b}$ & $20,70 \mathrm{~b}$ \\
A2 & $15,99 \mathrm{~b}$ & $19,04 \mathrm{c}$ & $25,79 \mathrm{c}$ \\
A3 & $16,12 \mathrm{~b}$ & $20,81 \mathrm{c}$ & $32,06 \mathrm{~d}$ \\
\hline BNT 5\% & $\mathbf{2 , 0 8}$ & $\mathbf{2 , 1 9}$ & $\mathbf{2 , 6 4}$
\end{tabular}

Keterangan: Angka-angka yang diikuti oleh huruf yang sama pada kolom yang sama pengatur tumbuh Rootone-F termasuk dalam kelompok auksin. Rootone-F sangat aktif mempercepat dan memperbanyak keluarnya akar sehingga penyerapan air dan unsur hara tanaman akan banyak dan dapat mengimbangi penguapan air pada bagian tanaman yang berada di atas tanah dan secara ekonomis penggunaan Rootone-F dapat menghemat tenaga, waktu, dan biaya.

Hasil analisis sidik ragam menunjukan bahwa, waktu perendaman stek vanili dengan zat pengatur tumbuh Rootone-F memberikan pengaruh yang sangat nyata pada berat kering yang dari stek vanili (Vanilla planifolia Andrew). Berat kering tertinggi pada perlakuan A3 dan terendah pada perlakuan A0. (Tabel 8).

\section{Berat Kering.}

\footnotetext{
berarti tidak berbeda nyata pada taraf uji BNT 5\%.
} 
Dari hasil analisi menunjukan waktu perendaman 15 menit berpengaruh nyata terhadap berat kering stek vanili. Berat kering menunjukkan berat total stek vanili pada kadar air $0 \%$. Berat kering teringgi dihasilkan oleh perlakuan dengan waktu perendaman 15 menit. Pada perlakuan waktu perendaman 15 menit menghasilkan stek vanili dengan kandungan bahan organik dan unsur mineral yang tinggi. Tingginya unsur penyusun stek vanili terjadi karena aktifnya akar menyerap unsur hara dari media tanam Waluyo (2000), perbedaan berat kering sangat dipengaruhi oleh jenis stek, dapat dilihat bahwa stek pucuk memiliki persentase paling tinggi karena kandungan $\mathrm{C} / \mathrm{N}$ rasionya juga kandungan hormon endogen yang dimilikinya. Nilai $\mathrm{C} / \mathrm{N}$ rasio merupakan suatu nilai yang menyatakan perbandingan antara karbohidrat dengan nitrogen yang dikandung dalam stek. Hormon endogen yang mendukung pertumbuhan stek adalah hormon-hormon dari golongan auksin, apabila tidak mencukupi maka hormon tersebut dapat kita tambahkan dengan pemberian Rootone-f, cara perendaman menyebabkan tanaman menyerap Rootone-f lebih banyak dibandingkan tanaman dengan cara pemberian pasta. Stek yang memiliki hormon auksin yang cukup akan mampu bertunas, sedangkan fungsi dari $\mathrm{C} / \mathrm{N}$ rasio adalah untuk mendukung pertumbuhan tunas tersebut. Stek vanili yag diinduksi NAA memiliki kandungan karbohidrat dan auksin yang lebih besar sehingga memungkinkan stek vanili memiliki berat kering yang lebih tinggi.( Waluyo (2000)

\section{Simpulan}

1. Hasil penelitian menunjukkan bahwa pertumbuhan akar terbaik pada perlakuan dengan waktu perendaman 15 menit (A3) yang ditunjukkan melalui jumlah akar terbanyak (3,08 buah), panjang akar $(10,98 \mathrm{~cm})$ dan diameter akar tertinggi $(0,53 \mathrm{~cm})$ pada $28 \mathrm{HST}$.

2. Hasil penelitian menunjukkan bahwa pertumbuhan tunas terbaik pada perlakuan dengan waktu perendaman 15 menit (A3) yang ditunjukkan melalui jumlah hari tumbuh tunas pertama tercepat $(15,66$ hari), jumlah tunas terbanyak $(2,33$ buah), panjang tunas $(5,23$ $\mathrm{cm})$, berat basah $(217,44 \mathrm{gr})$ dan berat kering tertinggi $(32,06$ gr) pada $28 \mathrm{HST}$.

\section{UCAPAN TERIMA KASIH}

Pada kesempatan ini penulis ingin mengucapkan terima kasih kepada semua pihak yang telah membantu dengan caranya masing-masing dalam melengkapi tulisan ini.

\section{DAFTAR PUSTAKA}

Anonimus. 1987. Pangram Rootone - F terhadap pertumbuhan Anakan Jelutung (Dyera costulata Hook F).

Buletin Penelitian Kehutanan Pematang Siantar. 1995. Pedoman Penggunaan Hormon Tumbuh Akar Pada Pembibitan Beberapa Tanaman Kehutanan. Departemen Kehutanan Direktorat Jenderal Reboisasi dan Rehabilitasi Lahan. Jakarta.

Audus, L. J. 1963. Plant Growth Substances. Interscience Publ. Inc. New York.

Avery, G. S., Johnson E. B. 1947. Hormones and Horticulture. 
McGraw-Hill Book Co. Inc. New York.

Departemen Kehutanan. 2004. Sepuluh Peringkat Benih Marketable. Ditjen Rehabilitasi lahan dan Perhutanan Sosial. Dephut. Jakarta.

Dwijoseputro. 1980. Pengantar Fisiologi Tumbuhan. PT. Gramedia Jakarta.

Gadner., Peace., Mitchell. 1991. Fisiologi Tanaman Budidaya. Universitas Indonesia. Jakarta.

Goldsworthy, P. R ., Fisher N.M. 1992. Fisiologi Tanaman Budidaya Tropik. Gadjah Mada University Press, Yogyakarta

Gomez, K.C., Gomez. A. 1995. Prosedur Statistik Untuk Penelitian Pertanian. Edisi Kedua. Universitas Indonesia. Jakarta.

Haber. 1976. Plant Propagation. Jhon Wiley and Sons Inc. New York.

Hartman, H. T., D. E. Kester. 1983. Plant Propagation, Principles and Practice. Prentice Hall of India. New Delhi.

Heddy, 1991. Hormon Tumbuh. Penerbit CV. Rajawali. Jakarta.

Kramer, K. 1960. Phisiology of Tress. Mc Graw Hill Book Co. New York

Kusumo. 1984. Zat Pengatur Tumbuh. CV Yasaguna. Jakarta.

Latifah, Irma. (2006). Pengaruh Konsentrasi Zat Pengatur Tumbuh Iba Dan Natrium Terhadap Viabilitas Optimal Pada Stek Vanili (Vanilla

Pratiknyo, P. S, 2002, Perbanyakan Dan Budidaya Tanaman Buah Buahan.International Center For Research In Agroforestry dan Winrock International, planifolia

Andrews).

Undergraduate thesis, University of Muhammadiyah Malang.

Leopold, A. C. 1963. Auxin and Plant Growth. Univ. California Press. Berkeley, Los Angeles.

Lewerissa, E. Penggaruh Penggunaan Rootone - F Terhadap Pertumbuhan Stek Pucuk Tanaman Meranti Putih (Shorea asamica, Dyer) dan Meranti Merah (Shorea selanica, BL) Pada Kebun Pangkas PT. MANGTIP UNID II. Jurusan Kehutanan Fakultas Pertanian Universitas Pattimura.

Manurung, S. O, 1987. Status dan Potensi Zat Pengatur Tumbuh Serta Penggunaan Rootone-F Dalam Perbanyakan Tanaman. Makalah Seminar Rootone-F ; Ditjen Reboisasi dan Rehabilitasi Lahan, Dept. Kehutanan. Jakarta.

Nura, W. 2005.Pengaruh Cara Pemberian Rootone-F dan Jenis Stek Terhadap Induksi Akar Stek Gmelina (Gmelina arborea linn). Bogor

Perez.,Silva, A. 2005. GC-MS and GColfactometry analysis of aroma compound in a representative organic aroma extract from cured vanilla (Vanilla planifolia G. Jackson) beans. J Food Chemistry (http://www.kpel.or.id/TTGP/ komoditi/PANILI1 2005).Tanggal 20 Juli 2010.

Puttileihalat, M. 2001. Pengaruh Rootone-F dan Ukuran Diameter Stek Terhadap Pertumbuhan Tunas Dari Stek Pulai Gading (Alstonia scholaris, R. Br) Jurusan 
Kehutanan Fakultas Pertanian Universitas Pattimura.

Rochiman., Hariadi, 1973. Pembiakan Vegetatif Departemen Agromoni. Fakultas Pertanian IPB. Bogor.

Salibury .,Ross. 1995. Fisiologi Tumbuhan Jilid 3. Penerbit ITB. Bandung.

Tini., Amri. 2002. Mengebunkan Jati Unggul Pilihan Investasi Prospektif. Agromedia Pustaka. Jakarta.

Waliszewski, K., Pardio, V., Ovando, SL. 2003. Effect of commercial cellulases pretreatment on the kinetics of vanilin extraction from vanilla pods.

http://ift.confex.com/ift/2003/t echprogram/paper_20264.htm. Tanggal 20 Juli 2010

Waluyo, R. 2000. Studi Penggunaan Bahan Pelembab Pada Penyimpanan dan Lama Penyimpanan Terhadap Persentase Tumbuh Stek.. Fakultas Kehutanan, IPB. Bogor.

Weaver, R. J. 1972. Plant Growth Substances in Agriculture. W. H. Freeman Co. San Fransisco.

Wudianto, R. 1999. Membuat Setek, Cangkok, dan Okulasi. Penebar Swadaya. Jakarta.

Yasman., Smits. 1998. Metode Pembuatan Stek Dipterocarpaseae. Badan Penelitian Dan Penembangan Kehutanan. Balai Penelitian Kehutanan. Samarinda. 